\title{
The Impact of Soaking and Germination on Chemical Composition, Carbohydrate Fractions, Digestibility, Antinutritional Factors and Minerals Content of Some Legumes and Cereals Grain Seeds
}

\author{
Samia El-Safy, F.; Rabab, H.A. Salem ${ }^{1}$ and Ensaf Mukhtar, Y.Y. ${ }^{2}$
}

\begin{abstract}
Germination of legumes and cereals seed causes some important changes in the biochemical and a nutritional characteristic of the legumes that may be beneficial to human's health and nutritional status. This study evaluated the effects of soaking for 6 and $12 \mathrm{hr}$ and germination for 2 and 4 days with or without light on the chemical composition, carbohydrate fractions (starch, total sugars, reducing sugars and total carbohydrates), in vitro starch and protein digestibility, antinutritional factors, minerals content (macro and micro elements, ppm) of some legume (peas, lentils, chickpea and faba bean) and cereal grains (oats and wheat). The proximate composition in studied seeds was affected by soaking and germination. In germinated samples, moisture and protein and total dietary fiber contents increased while carbohydrate, and fat were decreased. Germination caused increase in vitro starch and protein digestibility contents of all the legume and cereal samples. Phytic acid and trypsin inhibitors contents were decreased in germinated legumes and cereals. The decreased in phytic acid and trypsin inhibitors contents were due to enzymatic changes during soaking and germination period in seeds. The presence or absence of light during the germination process did not affect the results achieved.
\end{abstract}

It can be concluded that soaking and sprouting improved the nutritional worth of the selected legumes and cereals in terms of higher concentration of nutrients, reduced phytic acid, trypsin inhibitors and improved protein content and ascorbic acid. Germinated legumes and cereals can be incorporated with wheat-based food product such as bread or pasta to improve nutrition content.

Key words: Soaking, germination, legumes, cereals, chemical composition, carbohydrate fractions, in vitro starch and protein digestibility, antinutritional factors, mineral contents

\section{INTRODUCTION}

Legumes play an important role in the agriculture and diet of many developing countries and are a major source of dietary nutrients for many people (Ghavidel and Prakash, 2007). They are a good and inexpensive source of energy, dietary proteins, carbohydrates, vitamins and minerals. However, their role appears to be limited because of several factors including low protein and starch digestibility (Negi, et al., 2001), poor mineral bioavailability (Kamchan et al., 2004), and high amounts of antinutritional factors (i.e. trypsin inhibitors, alpha -galactosides, inositol phosphates) in the raw seeds that need to be reduced by processing before consumption (Augustin et al., 1989; Kaushik et al., 2010).

Cereals, particularly wheat, are important components of the daily diet, providing carbohydrates, proteins, dietary fibers and vitamins to less privilege in many countries. Wheat is one of the most consumed cereal grains worldwide and makes up a substantial part of the human diet (Punder and Pruimboom, 2013). Native oat is known as a health promoting cereal with high content of soluble dietary fiber, beneficial fatty acid content and a large selection of vitamins, minerals, sterols and antioxidants (Tian et al., 2010), the studies of germinated /malted oat are few. In recent years, Oats have attracted research and commercial attention mainly due to their high contents of $\beta$-glucan and phenolic compounds with high antioxidant activities (Malkki et al., 2004).

Soaking is the first step in water penetration, which transforms the inactive tissue into living tissue. In this step, the grain's metabolism is activated in preparation for germination (Maisont and Narkrugsa, 2010). Soaking and germination of cereal and legumes were also found to reduce trypsin inhibitor activity level and flatulence causing oligosaccharides (namely stachyose and raffinose), thereby increasing protein digestibility and improving sensory properties (Zanabria et al., 2006; Osman, 2007).

Germination is an inexpensive and effective technology for improving nutrients availability and diminishing anti-nutritional factors in present in legume and cereal grains and maximizes the levels of some of the utilizable nutrients (Inyang and Zakare, 2008; Maisont and Narkrugsa, 2010). Gupta and Sehgal

\footnotetext{
${ }^{1}$ Food Sciences and Technology Department,

${ }^{2-N}$ Nutrition and Food Sciences Department,

Faculty of Home Economics, Al Azhar University, Nawag, Tanta,

Gharbia, Egypt.

E-mail: dr_samiaelsafy@yahoo.com

lenaspp@yahoo.com

Received November 1, 2013, Accepted December 30, 2013
} 
(1991) reported a decrease in phytic acid content of cereal grain used for preparation of weaning foods as results of soaking and germination. Germinated seeds are good source of ascorbic acid, riboflavin, choline, thiamine, tocopheroles and pantothenic acid (Sangronis and Machado, 2007).

In recent years, germinated seeds have gained a lot of popularity and widely accepted as a functional food because of its nutritious and heath benefits in several aspects (Moongngarm, 2011). The practice of sprouting of cereal grains has become popular in the western world. They can be used in many different foods including breakfast items, salads, soups, casseroles, pasta and baked products (Lorenz ,1980).

The presence of light advances the metabolic changes that take place during the different stages of germination, and so it is necessary to evaluate how these changes influence the bioavailability of essential nutrients (Urbano et al., 2005).

There have been very few comparative studies in which the same seeds were exposed to light germination or germinated entirely in darkness while holding other germination conditions constant (Kuo et al., 2004; Vidal-Valverde et al., 2002).

Therefore, the purpose of the current expermint was to study the effect of some domestic traditional processes, such soaking and germination process in presence or absence of light on the chemical composition, carbohydrate fractions, digestibility of starch and protein, antinutritional factors, mineral contents in some legumse (peas, lentils, chickpea and faba bean) and cereal grains (oats and wheat).

\section{MATERIALIS AND METHODS}

\section{Materials:}

Three whole legumes and two cereal grains, namely pea (Pisum sativum), lentils (Lens esculenta), chickpea (Cicer arietinum), faba bean (Vicia faba), oats (Avena sativa) and wheat (Triticum vulgare) were obtained from $\mathrm{El}$ - Behira governorate, and used for the germination experiments. Samples were washed and cleaned with tap water before soaked.

\section{Methods:}

1- Technological methods :

\section{Soaking: -}

Legumes and cereal seeds were first cleaned manually to remove broken seeds, dust and other extraneous materials and then soaked in $2500 \mathrm{ml}$ of $0.07 \%$ sodium hypochlorite solution for $30 \mathrm{~min}$ at room temperature. Seeds were then drained and washed to neutral $\mathrm{pH}$ and then soaked in distilled water for 6 and $12 \mathrm{~h}$ at ambient temperature. A seed to water ratio of
1:10 (w/v) was used. The unimbibed water was discarded. The soaked seeds were rinsed twice in distilled water and then dried at $55-60^{\circ} \mathrm{C}$ (VidalValverde et al., 2002).

\section{Germination:-}

The soaked seeds were allow to germinate under a wet muslin cloth for 0,2 and $4 \mathrm{~d}$ with or without light (G0,G2DL, G2DD, G4DL and G4DD) at $37^{\circ} \mathrm{C}$ and 99\% relative humidity, with frequent watering as described by Obizoba and Atii (1994). Ungerminated seeds served as control. The sprouts were rinsed in distilled water and dried at $60{ }^{\circ} \mathrm{C}$ for $12 \mathrm{~h}$ using air oven until constant weight was achieved. The dried samples of raw, soaked and germinated seeds were ground to fine powder in an electric grinder and then stored in plastic containers for further use.

\section{Chemical methods:}

\section{Proximate analyses:}

Proximate compositons of the food sample were determined in triplicate using the standard procedures of Association of Official Analytical Chemists (AOAC, 2005). Moisture content, crude protein (Kjeldahl method), crude fat (solvent extraction), crude fiber and ash were determined using standard methods (AOAC, 2005).

\section{Carbohydrate fractions:}

Starch was determined as glucose after hydrolyzation by HCL (AOAC, 2005). The total carbohydrate content was determined by difference, that is addition of moisture, fat, crude protein, ash and crude fiber, which was subtracted from $100 \%$. This gave the amount of nitrogen free extract otherwise known as carbohydrate.

$\%$ Carbohydrate $=100-(\%$ Moisture $+\%$ Fat $+\%$ Ash $+\%$ Crude fiber $+\%$ Crude protein).

\section{Total sugar determination:}

Total sugar was determined according to the method of Dubois et al., (1956), with slight modification. Samples were thoroughly mixed with ethanol and diluted with water appropriately and filtered prior to addition of phenol and concentrated sulphuric acid and the absorbance read at $490 \mathrm{~nm}$ after $10 \mathrm{~min}$. Sugar content was calculated using a standard curve prepared using $0-100 \mu$ g glucose.

\section{Reducing sugars:}

Reducing sugars contents were colorimetrically determined according to the method of Miller (1959). Five grams of sample was extracted with $50 \mathrm{ml}$ of $70 \%$ ethanol and incubated in water bath at $70^{\circ} \mathrm{C}$ for 3 hours. Then, the solution was filtered. The filtrate was made up to $100 \mathrm{ml}$ with distilled water. Five $\mathrm{ml}$ of the filtrate was 
pipetted in test tube and $2 \mathrm{ml}$ of 3,5- dinitrosalicylic acid were added in test tube, shake well, heated exactly for $10 \mathrm{~min}$ in water bath at $100^{\circ} \mathrm{C}$ and cooled under stream of tap water. The color intensities measured at $550 \mathrm{~nm}$. Standard curve was made by using different concentrations of pure glucose solution.

\section{Ascorbic acid determination:}

Ascorbic acid was determined according to AOAC (2005) procedure using 2,6 - dichlorophenol indophenol dye.

\section{Nutritional methods:}

\section{Phytic acid determination:}

Phytic acid was extracted from each $3 \mathrm{~g}$ flour sample with $3 \%$ trichloroacetic acid by shaking at room temperature followed by high speed centrifugation as described by Wheeler and Ferrel (1971). This method depends on an iron to phosphorus ratio of 4:6. Five grams of the test sample was extracted with $3 \%$ trichloroacetic acid. The phytate was precipitated as ferric phytate and converted to ferric hydroxide and soluble sodium phytate by adding sodium hydroxide. The precipitate was dissolved in hot 3.2 N HNO and the colour read immediately at $480 \mathrm{~nm}$. The standard solution was prepared from $\mathrm{Fe}(\mathrm{NO} 3) 3$ and the iron content was extrapolated from $\mathrm{Fe}(\mathrm{NO} 3) 3$ standard curve. The phytate concentration was calculated from the iron results assuming a 4: 6 iron: phosphorus molecular ratio. The phytic acid was estimated by multiplying the amount of phytate-phosphorus by the factor 3.55 based on the empirical formula $\mathrm{C}_{6} \mathrm{P}_{6} \mathrm{O}_{24} \mathrm{H}_{18}$.

\section{Trypsin inhibition activity determination:}

The trypsin inhibition activity was assayed in terms of the extent to which an extract of the defatted flour inhibited the action of bovine trypsin on the substrate benzoyl-DL-arginine-p-nitrianilide hydrochloric (Kakade et al., 1969).

\section{Starch digestibility:}

In vitro starch digestibility was assessed by employing pancreatic amylase and incubating at $37^{\circ} \mathrm{C}$ for $2 \mathrm{~h}$. Liberated maltose was measured colorimetrically by using dinitrosalicylic acid reagent (Singh et al., 1982).

\section{Protein digestibility:}

In vitro protein digestibility was assessed by employing pepsin and pancreatin (Akeson and Stahmann, 1964). The nitrogen contents of the sample and undigested residue were determined by the microkjeldahl method (AOAC, 2005). The digested protein of the sample was calculated by subtracting residual protein from total protein of the sample.
Protein gigestibility $(\%)=$ Digested protein $/$ Total protein $\times 100$

\section{Mineral analysis:}

The standard method described by Association of Official Chemists was used for mineral content analysis of the samples (AOAC, 2005). Calcium (Ca), Magnesium (Mg), Potassium (K), Sodium (Na), Iron $(\mathrm{Fe})$, Manganese $(\mathrm{Mn})$ and Zinc ( $\mathrm{Zn})$ were determined using Atomic Absorption Spectrophotometer (PERKIN - ELMER, 2380). All values were expressed in ppm.

\section{Statistical analyses:}

The data obtained were subjected to analysis of variance according to SPSS, (1997). Significant differences among individual means were analyzed by Duncan, s multiple range test (Duncan,1955).

\section{RESULTS AND DISCUSSION}

Effect soaking and germination on proximate composition of some legumes and cereals:

The effect of germination on the proximate composition of peas, lentils, chickpea, faba bean, oats and wheat seeds, both raw, soaked ( 6 and $12 \mathrm{~h}$ ) and after germination for periods of 0,2 , or 4 day in presence of light and in darkness are given in Table (1). The moisture and protein contents were increased after soaking and germination in both legume and cereal samples, while their crude lipids, total carbohydrate and ash contents decreased. The moisture content increased for example, from $18 \%$ in raw peas to $78 \%$ after $12 \mathrm{~h}$ soaking and 4 day germination. It is clear that oats contain more crude lipids than other seed samples. These results are in agreement with Saastamoinen et al., (1989) who reported that oats contain lipids, normally 59\%. As germination proceeds, legumes took up water from the surrounding in order for the metabolic process to commence. Dry legumes absorb water rapidly, influenced by the structure of the legume. The increase in water uptake with time is due to the increasing number of cells within the seed becoming hydrated (Nonogaki et al., 2010). Many researchers observed significant increase in protein content of cereal and legumes (Traore et al., 2004; Oloyo, 2004; Alonso et al., 2000).

Reports on changes in total protein content during germination show either an increase, a decrease or indifference. Total protein content was found to increase significantly during germination in wheat, triticale. barley, rice, rye and oat (Miller 1978, Nielsen et al., 1978).

Soaking was found to cause slightly change in fat content of seed samples, whereas, germination caused significant decrease in fat content. 
Table 1. Effect of soaking period and germination conditions on the proximate composition of some legumes and cereals

\begin{tabular}{|c|c|c|c|c|c|c|c|c|c|c|}
\hline \multirow{3}{*}{ Samples } & \multicolumn{2}{|c|}{ Moistur \% } & \multicolumn{2}{|c|}{ Protein \% } & \multicolumn{2}{|c|}{ Lipids \% } & \multicolumn{2}{|c|}{ Ash \% } & \multicolumn{2}{|c|}{ Crude fiber $\%$} \\
\hline & \multicolumn{10}{|c|}{ Soaking periods (h) } \\
\hline & 6 & 12 & 6 & 12 & 6 & 12 & 6 & 12 & 6 & 12 \\
\hline \multicolumn{11}{|l|}{ Peas } \\
\hline Raw & $18.93 \pm .01$ & - & $27.86 \pm .12$ & - & $2.23 \pm .08$ & - & $3.18 \pm .11$ & - & $4.53 \pm .38$ & - \\
\hline G0 & $58.66 \pm .21$ & $64.22 \pm .02$ & $27.63 \pm .07$ & $27.22 \pm .10$ & $2.13 \pm .11$ & $2.16 \pm .05$ & $3.00 \pm .09$ & $2.96 \pm .12$ & $5.19 \pm .12$ & $5.66 \pm .13$ \\
\hline G2DL & $65.16 \pm .03$ & $68.12 \pm .15$ & $28.56 \pm .11$ & $28.43 \pm .11$ & $2.08 \pm .09$ & $2.12 \pm .11$ & $2.74 \pm .12$ & $2.70 \pm .22$ & $7.33 \pm .09$ & $7.94 \pm .07$ \\
\hline G4DL & $76.43 \pm .11$ & $78.30 \pm .17$ & $28.66 \pm .12$ & $28.46 \pm .12$ & $1.96 \pm .32$ & $1.88 \pm .12$ & $2.43 \pm .07$ & $2.28 \pm .04$ & $9.86 \pm .11$ & $10.33 \pm .12$ \\
\hline G2DD & $65.15 \pm .20$ & $68.15 \pm .03$ & $28.73 \pm .11$ & $28.54 \pm .09$ & $2.12 \pm .11$ & $2.13 \pm .21$ & $2.33 \pm .17$ & $2.21 \pm .07$ & $7.30 \pm .07$ & $8.06 \pm .56$ \\
\hline G4DD & $76.39 \pm .13$ & $78.23 \pm .11$ & $29.01 \pm .05$ & $28.95 \pm .12$ & $2.00 \pm .12$ & $1.79 \pm .43$ & $2.16 \pm .22$ & $2.11 \pm .33$ & $10.02 \pm .11$ & $10.30 \pm .04$ \\
\hline \multicolumn{11}{|l|}{ Lentils } \\
\hline Raw & $12.2 \pm .12$ & - & $25.33 \pm .11$ & - & $2.18 \pm .01$ & - & $4.26 \pm .11$ & - & $7.57 \pm .12$ & - \\
\hline G0 & $57.33 \pm .07$ & $59.16 \pm .11$ & $25.12 \pm .01$ & $25.09 \pm .11$ & $1.86 \pm .09$ & $1.88 \pm .03$ & $3.53 \pm .12$ & $3.50 \pm .01$ & $8.33 \pm .04$ & $9.16 \pm .07$ \\
\hline G2DL & $59.42 \pm .11$ & $61.52 \pm .08$ & $25.65 \pm .09$ & $25.44 \pm .01$ & $2.09 \pm .10$ & $2.04 \pm .07$ & $3.18 \pm .07$ & $3.11 \pm .10$ & $10.65 \pm .08$ & $11.36 \pm .12$ \\
\hline G4DL & $62.19 \pm .12$ & $66.83 \pm .12$ & $25.87 \pm .11$ & $25.63 \pm .21$ & $2.01 \pm .05$ & $2.00 \pm .10$ & $2.86 \pm .08$ & $2.83 \pm .003$ & $12.74 \pm .11$ & $12.42 \pm .01$ \\
\hline G2DD & $59.38 \pm .06$ & $61.36 \pm .03$ & $26.16 \pm .01$ & $26.02 \pm .01$ & $2.11 \pm .12$ & $1.98 \pm .11$ & $3.12 \pm .01$ & $3.00 \pm .11$ & $10.62 \pm .08$ & $11.37 \pm .11$ \\
\hline G4DD & $62.14 \pm .11$ & $66.78 \pm .11$ & $26.23 \pm .15$ & $26.12 \pm .31$ & $2.00 \pm .11$ & $2.00 \pm .11$ & $2.77 \pm .11$ & $2.52 \pm .10$ & $12.77 \pm .03$ & $12.40 \pm .08$ \\
\hline \multicolumn{11}{|l|}{ Jhickpea } \\
\hline Raw & $14.22 \pm .10$ & - & $30.41 \pm .06$ & - & $6.46 \pm .03$ & - & $3.72 \pm .02$ & - & $5.62 \pm .10$ & - \\
\hline G0 & $62.19 \pm .11$ & $64.32 \pm .11$ & $29.63 \pm .01$ & $29.21 \pm .01$ & $5.45 \pm .08$ & $5.43 \pm .32$ & $3.14 \pm .11$ & $3.12 \pm .10$ & $7.36 \pm .11$ & $7.92 \pm .12$ \\
\hline G2DL & $63.67 \pm .08$ & $68.46 \pm .03$ & $31.30 \pm .21$ & $31.09 \pm .12$ & $5.33 \pm .12$ & $5.26 \pm .11$ & $3.02 \pm .01$ & $2.98 \pm .21$ & $9.47 \pm .07$ & $10.36 \pm .11$ \\
\hline G4DL & $71.43 \pm .10$ & $73.23 \pm .11$ & $32.12 \pm .40$ & $32.22 \pm .09$ & $5.21 \pm .10$ & $5.15 \pm .06$ & $3.09 \pm .05$ & $2.88 \pm .12$ & $11.52 \pm .04$ & $12.48 \pm .04$ \\
\hline G2DD & $63.62 \pm .09$ & $68.32 \pm .07$ & $31.16 \pm .11$ & $32.13 \pm .01$ & $4.36 \pm .05$ & $4.28 \pm .11$ & $3.00 \pm .10$ & $2.98 \pm .06$ & $9.44 \pm .31$ & $10.33 \pm .23$ \\
\hline G4DD & $72.11 \pm .07$ & $73.06 \pm .03$ & $32.34 \pm .04$ & $32.24 \pm .12$ & $4.32 \pm .41$ & $4.14 \pm .60$ & $2.98 \pm .16$ & $2.77 \pm .09$ & $11.50 \pm .18$ & $12.42 \pm .05$ \\
\hline \multicolumn{11}{|l|}{ Beans } \\
\hline Raw & $10.46 \pm .11$ & - & $31.35 \pm .06$ & - & $1.89 \pm .01$ & - & $12.38 \pm .90$ & - & $4.88 \pm .06$ & - \\
\hline G0 & $60.52 \pm .03$ & $62.33 \pm .07$ & $31.11 \pm .01$ & $31.09 \pm .08$ & $183 \pm .00$ & $1.81 \pm .03$ & $10.25 \pm .02$ & $10.16 \pm .21$ & $6.73 \pm .03$ & $7.82 \pm .12$ \\
\hline G2DL & $63.43 \pm .21$ & $65.26 \pm .11$ & $32.45 \pm .12$ & $32.67 \pm .21$ & $2.15 \pm .12$ & $1.89 \pm .11$ & $9.58 \pm .11$ & $9.42 \pm .06$ & $7.48 \pm .11$ & $8.67 \pm .03$ \\
\hline G4DL & $70.18 \pm .05$ & $73.44 \pm .03$ & $32.66 \pm .13$ & $32.77 \pm .11$ & $2.11 \pm .02$ & $2.11 \pm .04$ & $9.26 \pm .04$ & $9.15 \pm .11$ & $8.76 \pm .02$ & $10.77 \pm .11$ \\
\hline G2DD & $63.54 \pm .11$ & $65.24 \pm .21$ & $32.33 \pm .41$ & $32.45 \pm .31$ & $2.01 \pm .21$ & $2.13 \pm .21$ & $9.54 \pm .22$ & $9.33 \pm .04$ & $7.44 \pm .15$ & $8.60 \pm .03$ \\
\hline G4DD & $70.20 \pm .09$ & $72.96 \pm .02$ & $32.54 \pm .03$ & $32.68 \pm .00$ & $2.12 \pm .30$ & $2.14 \pm .04$ & $9.12 \pm .08$ & $9.09 \pm .12$ & $9.09 \pm .02$ & $10.78 \pm .23$ \\
\hline \multicolumn{11}{|l|}{ Oats } \\
\hline Raw & $12.76 \pm .05$ & - & $18.89 \pm .12$ & - & $8.46 \pm .06$ & - & $2.78 \pm .04$ & - & $6.75 \pm .06$ & - \\
\hline G0 & $59.18 \pm .03$ & $60.88 \pm .06$ & $19.55 \pm .04$ & $19.61 \pm .11$ & $7.74 \pm .09$ & $7.43 \pm .12$ & $2.44 \pm .08$ & $2.31 \pm .12$ & $7.23 \pm .12$ & $8.31 \pm .03$ \\
\hline G2DL & $61.32 \pm .12$ & $62.52 \pm .12$ & $21.76 \pm .09$ & $21.78 \pm .12$ & $7.52 \pm .11$ & $7.41 \pm .06$ & $2.22 \pm .11$ & $2.13 \pm .05$ & $8.34 \pm .11$ & $10.38 \pm .08$ \\
\hline G4DL & $66.43 \pm .04$ & $68.87 \pm .03$ & $24.33 \pm .41$ & $24.41 \pm .04$ & $7.24 \pm .03$ & $7.11 \pm .11$ & $2.18 \pm .05$ & $2.00 \pm .11$ & $10.56 \pm .06$ & $12.61 \pm .12$ \\
\hline G2DD & $61.30 \pm .11$ & $62.51 \pm .12$ & $22.79 \pm .12$ & $22.82 \pm .18$ & $7.41 \pm .12$ & $7.32 \pm .11$ & $2.18 \pm .12$ & $2.09 \pm .07$ & $8.42 \pm .06$ & $10.46 \pm .01$ \\
\hline G4DD & $66.22 \pm .08$ & $69.06 \pm .23$ & $24.41 \pm .07$ & $24.43 \pm .06$ & $7.00 \pm .12$ & $7.13 \pm .05$ & $2.15 \pm .11$ & $2.11 \pm .12$ & $10.62 \pm .11$ & $12.66 \pm .10$ \\
\hline \multicolumn{11}{|l|}{ Wheat } \\
\hline Raw & $13.23 \pm .12$ & - & $10.86 \pm .02$ & - & $1.97 \pm .22$ & - & $1.98 \pm .19$ & - & $9.46 \pm .12$ & - \\
\hline G0 & $60.13 \pm .06$ & $62.15 \pm .12$ & $10.34 \pm .09$ & $10.30 \pm .18$ & $1.56 \pm .12$ & $1.49 \pm .31$ & $1.94 \pm .07$ & $1.92 \pm .11$ & $12.78 \pm .03$ & $12.88 \pm .00$ \\
\hline G2DL & $64.28 \pm .03$ & $65.33 \pm .05$ & $13.65 \pm .12$ & $13.60 \pm .12$ & $1.42 \pm .09$ & $1.40 \pm .11$ & $1.91 \pm .11$ & $1.88 \pm .09$ & $13.86 \pm .12$ & $13.92 \pm .12$ \\
\hline G4DL & $69.45 \pm .06$ & $70.72 \pm .11$ & $13.76 \pm .08$ & $13.65 \pm .06$ & $1.12 \pm .02$ & $1.10 \pm .03$ & $1.84 \pm .10$ & $1.82 \pm .21$ & $15.96 \pm .11$ & $16.98 \pm .11$ \\
\hline G2DD & $64.21 \pm .12$ & $65.18 \pm .09$ & $13.81 \pm .12$ & $14.00 \pm .02$ & $1.33 \pm .12$ & $1.26 \pm .09$ & $1.92 \pm .003$ & $1.84 \pm .11$ & $13.84 \pm .12$ & $13.91 \pm .02$ \\
\hline G4DD & $69.06 \pm .17$ & $70.36 \pm .13$ & $14.06 \pm .01$ & $14.04 \pm .11$ & $1.10 \pm .03$ & $1.00 \pm 18$ & $1.83 \pm .12$ & $1.80 \pm .01$ & $15.97 \pm .08$ & $16.98 \pm .07$ \\
\hline
\end{tabular}

Eatch value is expressed as mean of triplicates \pm standard deviations.

$\mathrm{G} 0=$ ungerminated, $\mathrm{G} 2 \mathrm{Dl}=2$ day germinated in light, G4DL= 4day germinated in light, G2DD= 2day germinated in dark,

$\mathrm{G} 4 \mathrm{DD}=4$ day germinated in dark 
These results agree with Inyang and Idoko (2006) who reported reduction in fat content in malted millet during production. The decrease in fat content could be attributed to increase in lipolytic enzymes during germination or due to break down of fat by $\beta$-oxidation for energy purpose in embryo development. Increase in protein content was also noted by Camacho et al., (1992) during germination of beans, lentils, chick pea and pea's seeds. Ohtsubo et al., (2005) found an increment in crude protein of germinated brown rice. The increase in protein content could be attributed to a net synthesis of enzymic protein (e.g. proteases) by germinating seeds (Nzeribe and Nwasike, 1995). Other researchers have attributed the increase to the degradation of stored protein and synthesis of new protein and other materials while stated that the increase in protein on germination of corn was due to mobilization of storage nitrogen producing the nutritionally high quality protein which the young plant needs for its development.

Fat content was decreased in all germinated samples with significant decrease found in germinatedpeas, lentils, chickpea, faba bean, oats and wheat. Similar results occurred in study by El-Adawy et al.(2004), Ghavidel and Prakash (2007) and Hahm et al.(2008) where the fat content decrease with increase in the time of germination. This is because fat was used as the major source of carbon for seed growth (Bau et al., 1997). Hahm et al. (2008) also suggested that fatty acids are oxidized to carbon dioxide and water to generate energy for germination.

Ash content was significantly decreased in all germinated samples (Table 1). This reduction could be due to leaching of solid matter in soaking water (Ghavidel and Prakash, 2007). Wang et al., (1997) reported that the differences in ash content after soaking for a specific time was due to decreased ash content. The decrease in ash content represents loss in minerals due to rootlet and washing of the rice in water to reduce the sour smell during the period of germination (Tatsadjieu et al., 2004).

Study by Azizah and Zainon (1997) demonstrated that total dietary fibre was decreased in soaked wheat, barley, peanut and mung bean, but conversely increased in soaked rice and soy bean. This indicates that germination process affect the level of total dietary fibre during the period of soaking before the actual phase of germination (Megat Rusy et al.,2011). In a similar study conducted on soybean, Jimenez et al., (1985) also noted an increase in the fiber and protein content of soybean seeds during sprouting.
The decreased carbohydrate levels of the germinated seeds might be due to increase in $\alpha$ - amylase activity (Lasekan, 1996). $\alpha$ - Amylase breaks down complex carbohydrates to simpler and more absorbable sugars which are utilized by the growing seedling during early stages of germination.

Germination meanwhile, altered the biochemical composition of legumes. Decrease of carbohydrate level is beneficial to diabetes mellitus patients. In addition, increase of total dietary fiber and decrease of fat content can give benefit to people with cardiovascular disease and hypercholesterolemia (Megat Rusy et al., 2011).

Finally, germination did affect the proximate composition of the seeds of the plants, but though differently. Fat content of control seeds ranged from $0.89 \mathrm{~g} / 100 \mathrm{~g}$ in lentil to $5.45 \mathrm{~g} / 100 \mathrm{~g}$ in chickpea. On germination, there was a statistically significant decrease of fat content, which could be due to total solid loss during soaking prior to germination (Wang et al., 1997) or use of fat as an energy source in sprouting process.

El-Adawy et al., (2003) reported significant increase in ash content during sprouting in mungbean, pea and lentil seed. The decrease in crude fat and carbohydrate contents during sprouting may have led to the apparent increase observed in ash and other chemical components. Several studies on the effect of germination on legumes found that germination can increase protein content and dietary fiber, reduce tannin and phytic acid content and increase mineral bioavailability (Hussein and Ghanem, 1999; Ghavidel and Prakash, 2006).

\section{Effect of soaking and germination on carbohydrate fractions and ascorbic acid content:}

Table 2 shows the carbohydrate fractions and vitamin $\mathrm{C}$ content of raw, soaked (for 6 and 12h) and germinated ( 2 and 4 days) some legume and cereal seeds in presence or absence light.

The decrease in the starch content of germinated seeds was found after germination was taken placed for 2-4 days due to the starch was broken down by amylase and resulting in increasing the concentration of simple sugars (Table,2). In this study, reducing sugar was found to increase with soaking and germination time, due to the hydrolysis of starch. The maximum content was observed at soaking for 12 hour and germination for 4 days. Starch in cotyledon wasbroken down into smaller molecules such as glucose and fructose to provide energy for cell division while the seeds mature and grow (Vidal-Valverde et al., 2002; Nonogaki et al., 2010). Ohtsubo et al., (2005) explained that carbohydrate breakdown in which $\alpha$-amylase activities were found to 
Table 2. Effect of soaking period and germination conditions on starch, total sugars, reducing sugars, total carbohydrates and ascorbic acid of legumes and cereals

\begin{tabular}{|c|c|c|c|c|c|c|c|c|c|c|}
\hline \multirow{3}{*}{ Samples } & \multicolumn{2}{|l|}{ Starch \% } & \multicolumn{2}{|c|}{ Total sugars \% } & \multicolumn{2}{|c|}{ Reducing sugars \% } & \multicolumn{2}{|c|}{ *Total carbohydrates \% } & \multicolumn{2}{|c|}{ Ascorbic acid (mg/100g } \\
\hline & \multicolumn{10}{|c|}{ Soaking periods (h) } \\
\hline & 6 & 12 & 6 & 12 & 6 & 12 & 6 & 12 & 6 & 12 \\
\hline \multicolumn{11}{|l|}{ Peas } \\
\hline Raw & $45.40 \pm .01$ & - & $6.80 \pm .12$ & - & $.85 \pm .02$ & - & $62.22 \pm .22$ & - & $.96 \pm .17$ & - \\
\hline G0 & $42.38 \pm .11$ & $40.87 \pm .11$ & $4.94 \pm .23$ & $6.54 \pm .13$ & $.55 \pm .13$ & $.49 \pm .31$ & $62.05 \pm .07$ & $60.00 \pm .12$ & $1.38 \pm .11$ & $1.94 \pm .22$ \\
\hline G2DL & $40.72 \pm .07$ & $38.16 \pm .07$ & $6.21 \pm .11$ & $18.33 \pm .11$ & $3.09 \pm .11$ & $5.66 \pm .12$ & $59.28 \pm .01$ & $58.80 \pm .09$ & $2.49 \pm .06$ & $3.35 \pm .12$ \\
\hline G4DL & $38.86 \pm .13$ & $35.42 \pm .12$ & $10.68 \pm .01$ & $19.84 \pm .01$ & $4.66 \pm .13$ & $7.48 \pm .08$ & $57.09 \pm .11$ & $57.05 \pm .11$ & $4.58 \pm .16$ & $5.62 \pm .06$ \\
\hline G2DD & $40.33 \pm .09$ & $37.36 \pm .09$ & $6.15 \pm .11$ & $18.28 \pm .13$ & $3.11 \pm .11$ & $6.88 \pm .11$ & $59.52 \pm .32$ & $59.06 \pm .02$ & $2.44 \pm .04$ & $3.33 \pm .18$ \\
\hline G4DD & $38.45 \pm .11$ & $36.17 \pm .31$ & $11.43 \pm .20$ & $19.56 \pm .11$ & $4.58 \pm .05$ & $7.44 \pm .06$ & $56.75 \pm .06$ & $56.85 \pm .62$ & $4.69 \pm .11$ & $6.35 \pm .04$ \\
\hline \multicolumn{11}{|l|}{ Lentils } \\
\hline Raw & $39.62 \pm .07$ & - & $10.82 \pm .13$ & - & $0.65 \pm .05$ & - & $60.66 \pm .80$ & - & $1.64 \pm .32$ & - \\
\hline G0 & $38.19 \pm .04$ & $36.53 \pm .12$ & $8.92 \pm .03$ & $7.17 \pm .12$ & $0.48 \pm .12$ & $0.36 \pm .12$ & $61.16 \pm .12$ & $60.37 \pm .07$ & $1.96 \pm .22$ & $1.99 \pm .53$ \\
\hline G2DL & $32.61 \pm .11$ & $30.46 \pm .08$ & $12.15 \pm .22$ & $12.66 \pm .11$ & $2.66 \pm .21$ & $3.05 \pm .31$ & $58.43 \pm .05$ & $58.05 \pm .23$ & $2.55 \pm .18$ & $3.18 \pm .32$ \\
\hline G4DL & $28.33 \pm .13$ & $27.33 \pm .23$ & $16.18 \pm .18$ & $15.45 \pm .06$ & $4.13 \pm .06$ & $5.72 \pm .11$ & $56.52 \pm .11$ & $57.12 \pm .11$ & $5.17 \pm .11$ & $5.33 \pm .12$ \\
\hline G2DD & $32.42 \pm .09$ & $31.41 \pm .07$ & $13.22 \pm .10$ & $12.60 \pm .11$ & $2.62 \pm .17$ & $3.01 \pm .07$ & $57.99 \pm .32$ & $57.64 \pm .08$ & $2.57 \pm .13$ & $3.22 \pm .11$ \\
\hline G4DD & $27.87 \pm .11$ & $27.14 \pm .11$ & $16.18 \pm .11$ & $14.98 \pm .03$ & $4.22 \pm .11$ & $6.11 \pm .11$ & $56.23 \pm .23$ & $56.96 \pm .44$ & $5.21 \pm .11$ & $6.08 \pm .05$ \\
\hline \multicolumn{11}{|c|}{ Chickpea } \\
\hline Raw & $42.36 \pm .13$ & - & $11.35 \pm .32$ & - & $0.97 \pm .43$ & - & $53.79 \pm .67$ & - & $1.36 \pm .12$ & - \\
\hline G0 & $40.13 \pm .07$ & $40.11 \pm .05$ & $10.44 \pm .17$ & $9.77 \pm .1 .11$ & $0.66 \pm .11$ & $0.53 \pm .11$ & $54.43 \pm .08$ & $54.32 \pm .16$ & $2.75 \pm .09$ & $2.89 \pm .21$ \\
\hline G2DL & $39.28 \pm .11$ & $38.62 \pm .08$ & $11.98 \pm .07$ & $12.78 \pm .73$ & $3.75 \pm .21$ & $4.16 \pm .43$ & $50.88 \pm .31$ & $50.31 \pm .03$ & $4.66 \pm .44$ & $5.34 \pm .08$ \\
\hline G4DL & $37.53 \pm .12$ & $35.47 \pm .11$ & $15.38 \pm .12$ & $16.48 \pm .32$ & $6.18 \pm .32$ & $7.34 \pm .22$ & $48.06 \pm .22$ & $47.27 \pm .42$ & $6.33 \pm .23$ & $7.29 \pm .12$ \\
\hline G2DD & $39.06 \pm .11$ & $37.66 \pm .12$ & $12.06 \pm .11$ & $12.73 \pm .12$ & $8 \mathrm{i} 3.66 \pm .11$ & $4.10 \pm .12$ & $52.04 \pm .09$ & $50.33 \pm .12$ & $4.68 \pm .12$ & $5.36 \pm .11$ \\
\hline G4DD & $37.14 \pm .09$ & $35.73 \pm .11$ & $15.22 \pm .09$ & $16.26 \pm .11$ & $6.32 \pm .04$ & $7.32 \pm .08$ & $48.87 \pm .31$ & $48.43 \pm 53$ & $6.36 \pm .17$ & $8.14 \pm .08$ \\
\hline \multicolumn{11}{|l|}{ Beans } \\
\hline Raw & $48.53 \pm .11$ & - & $13.72 \pm .52$ & - & $0.77 \pm 1.11$ & - & $49.50 \pm .45$ & - & $15.89 \pm .36$ & - \\
\hline G0 & $46.64 \pm .03$ & $46.18 \pm .12$ & $10.53 \pm .33$ & $9.16 \pm 1.11$ & $0.55 \pm .87$ & $0.43 \pm .55$ & $50.08 \pm .02$ & $49.12 \pm .08$ & $33.67 \pm .28$ & $34.54 \pm 1.1$ \\
\hline G2DL & $38.09 \pm .11$ & $36.22 \pm .08$ & $13.16 \pm .21$ & $13.89 \pm .37$ & $3.18 \pm .22$ & $4.56 \pm .23$ & $48.34 \pm .12$ & $47.35 \pm .14$ & $33.89 \pm .22$ & $34.89 \pm .84$ \\
\hline G4DL & $34.52 \pm .09$ & $32.43 \pm .11$ & $18.32 \pm .30$ & $19.76 \pm .33$ & $7.33 \pm .12$ & $6.88 \pm .08$ & $47.21 \pm .35$ & $45.20 \pm .01$ & $36.46 \pm .19$ & $38.66 \pm .32$ \\
\hline G2DD & $38.19 \pm .12$ & $37.11 \pm .06$ & $13.22 \pm .23$ & $13.87 \pm .26$ & $3.15 \pm .20$ & $4.67 \pm .12$ & $48.68 \pm .01$ & $47.52 \pm .25$ & $34.55 \pm .30$ & $35.17 \pm .22$ \\
\hline G4DD & $34.56 \pm .08$ & $33.12 \pm .12$ & $18.27 \pm .14$ & $19.72 \pm .03$ & $8.06 \pm .11$ & $7.32 \pm .05$ & $47.13 \pm .25$ & $45.34 \pm .36$ & $38.68 \pm .11$ & $39.36 \pm .08$ \\
\hline \multicolumn{11}{|l|}{ Oats } \\
\hline Raw & $59.86 \pm .12$ & - & $18.66 \pm .32$ & - & $3.75 \pm .55$ & - & $63.12 \pm .22$ & - & $.64 \pm .21$ & - \\
\hline G0 & $54.13 \pm .06$ & $52.66 \pm .32$ & $15.73 \pm .12$ & $13.83 \pm .16$ & $3.22 \pm .14$ & $3.11 \pm .09$ & $63.04 \pm .12$ & $62.34 \pm .08$ & $.71 \pm .04$ & $.88 \pm .06$ \\
\hline G2DL & $53.26 \pm .11$ & $51.54 \pm .11$ & $17.48 \pm .09$ & $16.88 \pm .05$ & $4.56 \pm .09$ & $5.63 \pm .11$ & $60.16 \pm .07$ & $58.30 \pm .23$ & $.98 \pm .12$ & $1.34 \pm .19$ \\
\hline G4DL & $51.34 \pm .09$ & $49.76 \pm .09$ & $20.55 \pm .12$ & $19.76 \pm .13$ & $6.87 \pm .11$ & $7.87 \pm .05$ & $55.69 \pm .45$ & $53.87 \pm 20$ & $1.56 \pm, 11$ & $2.48 \pm .08$ \\
\hline G2DD & $53.21 \pm .12$ & $50.81 \pm .01$ & $17.39 \pm .04$ & $17.34 \pm .08$ & $3.93 \pm .33$ & $5.66 \pm .04$ & $59.21 \pm .01$ & $57.31 \pm .11$ & $.93 \pm .02$ & $1.54 \pm .12$ \\
\hline G4DD & $50.66 \pm .03$ & $49.88 \pm .13$ & $20.52 \pm .01$ & $19.65 \pm .33$ & $6.85 \pm .06$ & $7.73 \pm .11$ & $55.82 \pm .00$ & $53.67 \pm .03$ & $1.64 \pm .17$ & $2.43 \pm .30$ \\
\hline \multicolumn{11}{|l|}{ Wheat } \\
\hline Raw & $68.42 \pm .12$ & - & $20.33 \pm .22$ & - & $2.13 \pm .21$ & - & $75.73 \pm .10$ & - & $.93 \pm .04$ & - \\
\hline G0 & $57.68 \pm .11$ & $54.65 \pm .12$ & $18.61 \pm .05$ & $17.32 \pm .1 .1$ & $5.66 \pm .05$ & $7.22 \pm .05$ & $73.38 \pm .03$ & $73.41 \pm .26$ & $1.44 \pm .01$ & $1.87 \pm .26$ \\
\hline G2DL & $48.87 \pm .09$ & $45.74 \pm .10$ & $19.56 \pm .11$ & $19.84 \pm .09$ & $7.32 \pm .11$ & $9.16 \pm .12$ & $69.16 \pm .33$ & $69.2 \pm .00$ & $1.78 \pm .23$ & $2.55 \pm .21$ \\
\hline G4DL & $45.49 \pm .06$ & $42.56 \pm .11$ & $22.74 \pm 08$ & $23.65 \pm .23$ & $10.66 \pm .02$ & $12.72 \pm .01$ & $67.32 \pm .19$ & $66.45 \pm .11$ & $2.65 \pm .00$ & $3.45 \pm .00$ \\
\hline G2DD & $48.44 \pm .11$ & $45.54 \pm .09$ & $20.32 \pm .11$ & $19.92 \pm .12$ & $7.30 \pm .22$ & $9.14 \pm .11$ & $69.10 \pm .70$ & $68.99 \pm .20$ & $1.67 \pm .12$ & $2.67 \pm .01$ \\
\hline G4DD & $45.11 \pm .05$ & $42.44 \pm .01$ & $23.22 \pm .03$ & $23.44 \pm 41$ & $10.48 \pm .19$ & $12.76 \pm .52$ & $67.04 \pm .14$ & $66.18 \pm .21$ & $2.78 \pm .00$ & $3.52 \pm .11$ \\
\hline
\end{tabular}

Eatch value is expressed as mean of triplicates \pm standard deviations.

$\mathrm{G} 0=$ ungerminated, $\mathrm{G} 2 \mathrm{Dl}=2$ day germinated in light, $\mathrm{G} 4 \mathrm{DL}=4$ day germinated in light, $\mathrm{G} 2 \mathrm{DD}=2$ day germinated in dark, G4DD= 4day germinated in dark

*Carbohydrates was calculated by difference 
parallel with the pattern of starch breakdown. Increase in $\alpha$-amylase activity during germination (Uriyo, 2001) could be a possible explanation of the total starch loss and appreciable improvement in percent glucose released.

From the tabulated data, it could be noticed that all the sugar contents decreased on soaking for 6 and $12 \mathrm{~h}$. Losses of sugars during soaking could be from simple diffusion of sugars after being solubilized. Soaking has been known to reduce the level of sugars in various pulses (Jood et al., 1998) whereas, germination caused increase in the content of sugars for 2 and 4 day. The increase in sugar content of soaked seeds during germination may be because of mobilization and hydrolysis of seed polysaccharides, leading to more available sugars.

The increase in total and reducing sugar contents after germination is mostly from the hydrolyzed starch by amylases. Therefore, the higher concentration of sugars was observed in germinated seeds that soaked and germinated for the longer times.

Germination resulted in increased ascorbic acid contents in all studied seeds during the course of germination (as shown in Table, 2).

Germination of grains and seeds is known to increase the content of certain vitamins, such as ascorbic acid (Riddoch et. al., 1998). Khalil et al., (2007) reported increase in ascorbic acid during chickpea germination, Yang et al., (2001) also noted similar changes in the concentration of vitamin $\mathrm{C}$ in wheat seed with germination.

Germinated cereals and legumes might be a useful source of ascorbic acid in developing countries where fruits and vegetables rich in ascorbic acid are often unavailable and/or too expensive to be added to the diet (Egli, 2001). Also, Sangronis and Machado, (2007) reported that germinated seeds are good source of ascorbic acid, riboflavin, choline, thiamine, tocopheroles and pantothenic acid. Riddoch et al. (1998) reported that many species of pulses produced significant quantities of vitamin $\mathrm{C}$ up to five days following germination in both light and dark although cooking caused a marked loss of ascorbate.

\section{Effect of soaking and germination on in vitro starch and protein digestibility and antinutritional of seed samples:}

Germination increased the in vitro starch and protein digestibility of all the samples as compared to control samples (Table 3), which is supported by the findings of Negi et al., (2001) and Archana et al., (2001). Germination may mobilize starch, seed proteins are metabolized and antimetabolites are catabolized, thereby resulting in improved digestibility of starch and protein of pulses. Sprouting causes mobilization of protein with the help of protease leading to the formation of peptides, oligopeptides and free amino acid (Jood et al. 1988).

Soaking could be one of the processes to remove soluble antinutritional factors, which can be eliminated with the discarded soaking solution (Akande and Fabiyi, 2010).

Table (3) presents the antinutritional factors of soaked and germinated some legume and cereal flours. Out of four legumes and two cereals analysed, control samples contained considerable amounts of phytic acid $(0.38-0.783 \mathrm{~g} / 100 \mathrm{~g})$. From the tabulated data, it clear that soaking for $12 \mathrm{hr}$ in water reduced phytic acid content more than $6 \mathrm{hr}$. This could be due to the fact that phytic acid in dried legumes and cereals exists wholly as a water soluble salt (probably potassium phytate) (Crean and Haisman, 1963). Decrease in phytic acid content during germination could be due to increase in phytase activity as reported by several authors in faba bean (Eskin and Wiebe, 1983), broad bean, chickpea and lentil (Egli et al., 2002) and several other legumes (Kyriakidis et al., 1998).

Soaking and germination treatments at room temperature for different times affected the trypsin inhibitors of studied seeds. There were slightly differences among germination with or without light. However, some metabolic reactions can take place during soaking which will affect some of the constituent compounds (Vidal-Valverde et al., 1992). Our results are in accordance with those of Vidal-Valverde et al., (1994) who found that soaking of lentils in water for $9 \mathrm{~h}$ at room temperature caused $11 \%$ reduction in trypsin inhibitors activity. Alaa et al., (1982) reported that the inhibitory activity of broad bean, chickpea, black eyed pea, lentil and mung bean decreased in most seeds after soaking in water at room temperature for $24 \mathrm{~h}$. Similar results were obtained by Osman, (2007) and Sangronis and Machado, (2007). From the tabulated data, it could be noticed that soaked and germinated oats had the highest phytic acid cntent compared to other studied seeds. Fretzdorff (1992) noticed that the degradation of phytate during germination was significantly lower in oat than in other cereals.

Gupta and Sehgal (1991) observed that decrease in phytic acid contents of cereal grains used for preparing weaning foods as a result of soaking and germination. The decrease in the level of phytic acid during soaking may be attributed to leaching out into soaking water under the concentration gradient (Abdullah et al., 1984). 
Table 3. Effect of soaking period and germination conditions on antinutritional factors, in vitro starch and protein digestibility of some legumes and cereals flours

\begin{tabular}{|c|c|c|c|c|c|c|c|c|}
\hline \multirow[t]{3}{*}{ Samples } & \multicolumn{2}{|c|}{$\begin{array}{l}\text { In vitro Starch } \\
\text { digestibility \% }\end{array}$} & \multicolumn{2}{|c|}{$\begin{array}{l}\text { In vitro protein } \\
\text { digestibility \% }\end{array}$} & \multicolumn{2}{|c|}{$\begin{array}{c}\text { Phytic acid } \\
\text { (mg/100g) }\end{array}$} & \multicolumn{2}{|c|}{$\begin{array}{l}\text { Trypsin inhibitor } \\
\text { (TIU/mg protein) }\end{array}$} \\
\hline & \multicolumn{8}{|c|}{ Soaking periods $(\mathrm{h})$} \\
\hline & 6 & 12 & 6 & 12 & 6 & 12 & 6 & 12 \\
\hline \multicolumn{9}{|l|}{ Peas } \\
\hline Raw & $54.82 \pm 1.2$ & - & $81.66 \pm .82$ & - & $.488 \pm .46$ & - & $7.98 \pm .12$ & - \\
\hline G0 & $56.36 \pm .90$ & $51.61 \pm .23$ & $86.37 \pm .35$ & $86.78 \pm 1.3$ & $.453 \pm .31$ & $.443 \pm .26$ & $7.33 \pm .05$ & $7.12 \pm .16$ \\
\hline G2DL & $58.27 \pm .46$ & $49.43 \pm 1.11$ & $88.31 \pm .16$ & $88.45 \pm .82$ & $.422 \pm .18$ & $.419 \pm .41$ & $6.84 \pm .14$ & $6.76 \pm .10$ \\
\hline G4DL & $48.31 \pm .43$ & $45.28 \pm .21$ & $90.42 \pm .27$ & $92.33 \pm .54$ & $.414 \pm .26$ & $.400 \pm .46$ & $5.77 \pm .07$ & $5.22 \pm .07$ \\
\hline G2DD & $50.22 \pm .16$ & $49.42 \pm .17$ & $88.52 \pm .23$ & $88.18 \pm .13$ & $.403 \pm .09$ & $.388 \pm .35$ & $6.68 \pm .23$ & $6.62 \pm .13$ \\
\hline G4DD & $49.17 \pm .27$ & $45.16 \pm .36 \mathrm{~s}$ & $89.27 \pm .42$ & $91.01 \pm .42$ & $.309 \pm .36$ & $.344 \pm .51$ & $5.73 \pm .11$ & $5.05 \pm .42$ \\
\hline \multicolumn{9}{|l|}{ Lentils } \\
\hline Raw & $38.66 \pm .36$ & - & $66.18 \pm .60$ & - & $.783 \pm .16$ & - & $29.18 \pm .82$ & - \\
\hline G0 & $36.41 \pm .82$ & $35.37 \pm .42$ & $68.13 \pm .18$ & $69.11 \pm .22$ & $.771 \pm .22$ & $.732 \pm .81$ & $27.33 \pm .09$ & $22.47 \pm .30$ \\
\hline G2DL & $34.38 \pm .42$ & $33.24 \pm .09$ & $70.26 \pm .21$ & $72.24 \pm .36$ & $.723 \pm .26$ & $.706 \pm .54$ & $23.46 \pm .15$ & $20.16 \pm .16$ \\
\hline G4DL & $30.35 \pm 1.3$ & $29.33 \pm 1.31$ & $74.33 \pm .09$ & $76.18 \pm .19$ & $.661 \pm .07$ & $.624 \pm .08$ & $19.34 \pm .11$ & $15.23 \pm .23$ \\
\hline G2DD & $34.16 \pm .90$ & $33.16 \pm .62$ & $71.32 \pm .31$ & $73.66 \pm .01$ & $.711 \pm .40$ & $.698 \pm .31$ & $23.34 \pm .44$ & $20.21 \pm .34$ \\
\hline G4DD & $31.03 \pm .12$ & $28.21 \pm .42$ & $74.16 \pm .16$ & $76.32 \pm .33$ & $.642 \pm .36$ & $.611 \pm .25$ & $19.07 \pm .40$ & $15.22 \pm .11$ \\
\hline \multicolumn{9}{|l|}{ Chickpea } \\
\hline Raw & $42.90 \pm 1.0$ & - & $64.67 \pm .16$ & - & $.566 \pm .42$ & - & $18.45 \pm .02$ & - \\
\hline G0 & $38.78 \pm .81$ & $36.88 \pm .24$ & $73.38 \pm .22$ & $74.55 \pm .35$ & $.546 \pm .31$ & $.532 \pm .36$ & $16.21 \pm .51$ & $14.56 \pm .18$ \\
\hline G2DL & $36.26 \pm .92$ & $34.19 \pm .18$ & $75.23 \pm .18$ & $76.43 \pm .16$ & $.522 \pm .26$ & $.518 \pm .71$ & $14.09 \pm .01$ & $13.66 \pm .09$ \\
\hline G4DL & $33.45 \pm .24$ & $32.47 \pm .61$ & $78.17 \pm .09$ & $79.78 \pm .30$ & $.482 \pm .08$ & $.467 \pm .46$ & $12.33 \pm .33$ & $12.28 \pm .11$ \\
\hline G2DD & $36.18 \pm .36$ & $34.23 \pm .52$ & $75.29 \pm 1.3$ & $77.35 \pm .42$ & $.526 \pm .24$ & $.509 \pm .77$ & $14.02 \pm .37$ & $13.49 \pm .51$ \\
\hline G4DD & $34.02 \pm .11$ & $33.17 \pm .09$ & $78.26 \pm .32$ & $80.07 \pm .53$ & $.477 \pm .36$ & $.435 \pm .44$ & $12.18 \pm .13$ & $12.00 \pm .01$ \\
\hline
\end{tabular}

\begin{tabular}{lcccccccc}
\hline Beans & & & & & & & \\
Raw & $44.16 \pm .42$ & - & $62.85 \pm .67$ & - & $.479 \pm .42$ & - & $26.18 \pm .01$ & - \\
G0 & $43.32 \pm .36$ & $42.45 \pm .61$ & $64.33 \pm .46$ & $64.89 \pm .34$ & $.360 \pm .33$ & $.346 \pm .05$ & $24.36 \pm .32$ & $23.11 \pm .08$ \\
G2DL & $42.51 \pm 1.2$ & $41.33 \pm .36$ & $66.26 \pm .34$ & $68.45 \pm .21$ & $.315 \pm .21$ & $.324 \pm .12$ & $22.36 \pm .20$ & $20.31 \pm .31$ \\
G4DL & $35.24 \pm .07$ & $34.17 \pm .42$ & $69.43 \pm .52$ & $70.55 \pm .32$ & $.309 \pm .09$ & $.311 \pm .06$ & $20.26 \pm .11$ & $18.78 \pm .23$ \\
G2DD & $42.16 \pm .46$ & $40.62 \pm .05$ & $66.52 \pm .16$ & $69.32 \pm .11$ & $.301 \pm .11$ & $.302 \pm .12$ & $22.43 \pm .03$ & $20.52 \pm .02$ \\
G4DD & $36.72 \pm .23$ & $32.57 \pm .16$ & $68.37 \pm .08$ & $73.22 \pm .26$ & $.304 \pm .05$ & $.284 \pm .03$ & $20.12 \pm .00$ & $18.72 \pm .14$ \\
\hline Oats & & & & & & & & \\
Raw & $34.55 \pm .02$ & - & $65.16 \pm .15$ & - & $2.38 \pm .71$ & - & $.513 \pm .09$ & - \\
G0 & $36.19 \pm 1.1$ & $37.34 \pm .33$ & $67.44 \pm .20$ & $68.42 \pm .00$ & $1.58 \pm .45$ & $1.28 \pm .1 .0$ & $.453 \pm .01$ & $.412 \pm .21$ \\
G2DL & $38.34 \pm .22$ & $39.12 \pm .05$ & $70.43 \pm .11$ & $72.23 \pm .23$ & $.86 \pm .09$ & $.76 \pm .17$ & $.383 \pm .13$ & $.322 \pm .11$ \\
G4DL & $45.16 \pm .07$ & $48.44 \pm .24$ & $75.27 \pm .42$ & $77.42 \pm .07$ & $.28 \pm .11$ & $.23 \pm .07$ & $.216 \pm .11$ & $.201 \pm .09$ \\
G2DD & $38.54 \pm .15$ & $39.04 \pm .12$ & $70.41 \pm .22$ & $72.41 \pm .21$ & $.80 \pm .03$ & $.75 \pm .11$ & $.340 \pm .06$ & $.321 \pm .00$ \\
G4DD & $45.18 \pm .03$ & $49.02 \pm .09$ & $75.24 \pm .11$ & $77.33 \pm .31$ & $.27 \pm .23$ & $.21 \pm .08$ & $.280 \pm .33$ & $.198 \pm .21$ \\
\hline Wheat & & & & & & & & \\
Raw & $32.78 \pm .11$ & - & $63.18 \pm .23$ & - & $.597 \pm 1.0$ & - & $.980 \pm .19$ & - \\
G0 & $35.71 \pm .23$ & $36.54 \pm .04$ & $64.39 \pm .12$ & $65.16 \pm .11$ & $.422 \pm .92$ & $.378 \pm .12$ & $.707 \pm .03$ & $.667 \pm .52$ \\
G2DL & $37.43 \pm .07$ & $38.87 \pm .11$ & $65.88 \pm .09$ & $67.33 \pm .43$ & $.412 \pm .23$ & $.345 \pm .33$ & $.645 \pm .12$ & $.583 \pm .33$ \\
G4DL & $42.77 \pm .20$ & $44.77 \pm .08$ & $68.34 \pm .11$ & $70.23 \pm .07$ & $.388 \pm .12$ & $.312 \pm .06$ & $.487 \pm .09$ & $.388 \pm .07$ \\
G2DD & $37.39 \pm .11$ & $38.66 \pm .32$ & $65.76 \pm .07$ & $67.30 \pm .23$ & $.377 \pm .22$ & $.287 \pm .12$ & $.632 \pm .11$ & $.578 \pm .11$ \\
G4DD & $42.65 \pm .17$ & $44.65 \pm .09$ & $68.12 \pm .00$ & $70.21 \pm .12$ & $.278 \pm .39$ & $.3 .05 \pm .03$ & $.499 \pm .08$ & $.391 \pm . .13$ \\
\hline
\end{tabular}

Eatch value is expressed as mean of triplicates \pm standard deviations.

$\mathrm{G} 0=$ ungerminated, $\mathrm{G} 2 \mathrm{Dl}=2$ day germinated in light, $\mathrm{G} 4 \mathrm{DL}=4$ day germinated in light, $\mathrm{G} 2 \mathrm{DD}=2$ day germinated in dark, $\mathrm{G} 4 \mathrm{DD}=$ 4day germinated in dark 
Table 4. Effect of soaking period and germination conditions on macro-elements (ppm) of selected legumes and cereals

\begin{tabular}{|c|c|c|c|c|c|c|c|c|}
\hline \multirow{3}{*}{ Samples } & \multicolumn{2}{|c|}{ (Ca) } & \multicolumn{2}{|c|}{ ( K ) } & \multicolumn{2}{|c|}{ (Mg) } & \multicolumn{2}{|c|}{ ( Na ) } \\
\hline & \multicolumn{8}{|c|}{ Soaking periods $(\mathrm{h})$} \\
\hline & 6 & 12 & 6 & 12 & 6 & 12 & 6 & 12 \\
\hline \multicolumn{9}{|l|}{ Peas } \\
\hline Raw & 690.0 & - & 687.40 & - & 115.43 & - & 200.34 & - \\
\hline G0 & 4880.0 & 4890.0 & 1048.0 & 1052.0 & 142.90 & 172.61 & 430.67 & 446.78 \\
\hline G2DL & 1410.0 & 1403.0 & 400.0 & 388.0 & 135.62 & 157.33 & 140.33 & 135.66 \\
\hline G4DL & 1490.0 & 1377.0 & 300.0 & 295.11 & 130.33 & 160.32 & 80.23 & 100.96 \\
\hline G2DD & 1412.0 & 1398.0 & 400.0 & 364.09 & 135.45 & 158.11 & 140.00 & 136.77 \\
\hline G4DD & 1478.0 & 1378.0 & 300.0 & 296.42 & 129.87 & 160.22 & 140.00 & 102.34 \\
\hline \multicolumn{9}{|l|}{ Lentils } \\
\hline Raw & 77.0 & - & 873.0 & - & 13.31 & - & 140.78 & - \\
\hline G0 & 163.88 & 161.92 & 600.22 & 562.09 & 39.60 & 45.67 & 115.44 & 100.23 \\
\hline G2DL & 161.72 & 160.34 & 553.23 & 523.11 & 20.55 & 45.89 & 100.23 & 95.46 \\
\hline G4DL & 155.0 & 153.10 & 508.12 & 449.13 & 16.12 & 30.34 & 93.45 & 90.78 \\
\hline G2DD & 161.0 & 157.5 & 516.71 & 522.43 & 34.77 & 42.99 & 100.28 & 93.33 \\
\hline G4DD & 154.0 & 150.3 & 500.89 & 428.65 & 33.89 & 25.88 & 91.79 & 91.27 \\
\hline \multicolumn{9}{|l|}{ Chickpea } \\
\hline Raw & 34.40 & - & 1127.22 & - & 130.67 & - & 360.33 & - \\
\hline G0 & 189.0 & 1880.0 & 518.98 & 1061.11 & 160.34 & 170.11 & 140.89 & 138.67 \\
\hline G2DL & 133.2 & 196.0 & 505.23 & 980.78 & 150.33 & 160.32 & 290.45 & 270.44 \\
\hline G4DL & 140.8 & 177.0 & 400.99 & 700.89 & 140.78 & 150.33 & 200.79 & 200.66 \\
\hline G2DD & 110.6 & 195.0 & 400.67 & 840.55 & 150.12 & 166.12 & 140.45 & 126.76 \\
\hline G4DD & 140.2 & 176.0 & 300.88 & 680.98 & 140.66 & 146.27 & 140.99 & 130.34 \\
\hline \multicolumn{9}{|l|}{ Beans } \\
\hline Raw & 40.27 & - & 500.76 & - & 125.44 & - & 140.34 & - \\
\hline G0 & 136.88 & 134.15 & 1377.12 & 1487.23 & 100.12 & 95.82 & 200.00 & 140.33 \\
\hline G2DL & 141.75 & 139.54 & 1365.45 & 1409.78 & 98.33 & 92.74 & 290.12 & 200.23 \\
\hline G4DL & 143.36 & 142.71 & 1370.09 & 1403.11 & 85.16 & 80.42 & 290.89 & 275.67 \\
\hline G2DD & 141.63 & 139.43 & 1366.45 & 1400.89 & 93.45 & 92.56 & 200.41 & 290.12 \\
\hline G4DD & 143.21 & 141.88 & 1372.78 & 1402.33 & 85.01 & 78.57 & 200.67 & 230.22 \\
\hline \multicolumn{9}{|l|}{ Oats } \\
\hline Raw & 68.50 & - & 400.43 & - & 128.22 & - & 140.22 & - \\
\hline G0 & 2110.0 & 1170.0 & 480.77 & 457.34 & 185.23 & 180.67 & 290.34 & 280.23 \\
\hline G2DL & 121.80 & 120.60 & 300.00 & 280.23 & 180.76 & 175.66 & 140.34 & 130.78 \\
\hline G4DL & 129.90 & 125.11 & 200.00 & 250.26 & 170.88 & 160.56 & 140.67 & 125.44 \\
\hline G2DD & 116.30 & 115.00 & 400.00 & 400.00 & 176.56 & 172.98 & 200.23 & 140.73 \\
\hline G4DD & 125.00 & 121.70 & 200.00 & 200.00 & 165.89 & 155.78 & 140.34 & 130.87 \\
\hline \multicolumn{9}{|l|}{ Wheat } \\
\hline Raw & 7.10 & - & 448.23 & - & 13.89 & - & 140.00 & - \\
\hline G0 & 1860.0 & 1190.0 & 450.12 & 455.22 & 289.23 & 284.34 & 150.12 & 160.34 \\
\hline G2DL & 110.90 & 160.50 & 200.98 & 400.78 & 25.56 & 10.89 & 100.56 & 95.56 \\
\hline G4DL & 112.30 & 144.00 & 100.23 & 279.55 & 30.35 & 12.45 & 80.45 & 76.99 \\
\hline G2DD & 118.90 & 157.00 & 300.45 & 400.00 & 28.33 & 11.98 & 100.98 & 96.55 \\
\hline G4DD & 138.00 & 143.70 & 100.34 & 280.12 & 31.63 & 14.67 & 80.23 & 77.58 \\
\hline
\end{tabular}

Eatch value is expressed as mean of triplicates \pm standard deviations.

$\mathrm{G} 0=$ ungerminated, $\mathrm{G} 2 \mathrm{Dl}=2$ day germinated in light, $\mathrm{G} 4 \mathrm{DL}=4$ day germinated in light, $\mathrm{G} 2 \mathrm{DD}=2$ day germinated in dark, $\mathrm{G} 4 \mathrm{DD}=$ 4day germinated in dark 
Table 5. Effect of soaking period and germination conditions on micro-elements (ppm) of selected legumes and cereals

\begin{tabular}{|c|c|c|c|c|c|c|}
\hline \multirow{3}{*}{$\begin{array}{l}\text { Samples } \\
\text { Lentils }\end{array}$} & \multirow{2}{*}{\multicolumn{2}{|c|}{$(\mathbf{F e})$}} & \multicolumn{2}{|c|}{$(\mathbf{Z n})$} & \multicolumn{2}{|c|}{ (Mn) } \\
\hline & & & \multicolumn{2}{|c|}{ Soaking periods (h) } & & \\
\hline & & & & & & \\
\hline Raw & 8.63 & - & 4.46 & - & 1.69 & - \\
\hline G0 & 6.74 & 5.34 & 3.36 & 3.22 & 1.23 & 1.44 \\
\hline G2DL & 8.88 & 7.89 & 4.33 & 4.12 & 1.53 & 1.73 \\
\hline G4DL & 10.87 & 11.34 & 6.55 & 5.88 & 1.81 & 2.11 \\
\hline G2DD & 8.78 & 7.66 & 4.31 & 4.32 & 1.55 & 1.68 \\
\hline G4DD & 10.65 & 11.43 & 6.46 & 5.75 & 2.06 & 2.13 \\
\hline \multicolumn{7}{|l|}{ Chickpea } \\
\hline Raw & 5.45 & - & 4.41 & - & 3.95 & - \\
\hline G0 & 4.67 & 4.33 & 3.88 & 3.27 & 3.24 & 3.11 \\
\hline G2DL & 5.88 & 6.22 & 4.47 & 4.97 & 3.85 & 4.32 \\
\hline G4DL & 7.67 & 8.56 & 6.11 & 7.12 & 4.44 & 6.52 \\
\hline G2DD & 5.67 & 6.12 & 4.33 & 4.87 & 3.82 & 4.22 \\
\hline G4DD & 7.54 & 8.33 & 6.03 & 7.34 & 4.29 & 5.98 \\
\hline \multicolumn{7}{|l|}{ Beans } \\
\hline Raw & 10.55 & - & 2.625 & - & 1.479 & - \\
\hline G0 & 9.06 & 8.78 & 2.432 & 2.512 & 1.425 & 1.233 \\
\hline G2DL & 11.23 & 10.77 & 2.750 & 2.978 & 1.559 & 1.457 \\
\hline G4DL & 13.54 & 12.89 & 3.234 & 3.664 & 2.354 & 1.987 \\
\hline G2DD & 11.61 & 10.65 & 2.674 & 3.012 & 1.522 & 1.522 \\
\hline G4DD & 13.33 & 12.57 & 3.312 & 3.965 & 2.277 & 2.010 \\
\hline Oats & & - & & & & \\
\hline Raw & 4.73 & 4.09 & 3.645 & - & 4.454 & - \\
\hline G0 & 3.22 & 2.89 & 3.022 & 2.898 & 4.211 & 4.104 \\
\hline G2DL & 5.66 & 4.99 & 3.586 & 3.885 & 4.887 & 4.644 \\
\hline G4DL & 7.23 & 7.11 & 5.223 & 5.264 & 6.642 & 5.887 \\
\hline G2DD & 5.56 & 5.12 & 3.522 & 3.921 & 4.769 & 4.567 \\
\hline G4DD & 7.11 & 7.03 & 5.211 & 5.370 & 6.445 & 5.875 \\
\hline \multicolumn{7}{|l|}{ Wheat } \\
\hline Raw & 0.58 & - & 0.324 & - & 4.055 & - \\
\hline G0 & 0.33 & 0.31 & 0.142 & 0.132 & 3.876 & 3.117 \\
\hline G2DL & 1.56 & 1.22 & 0.288 & 0.189 & 4.121 & 3.889 \\
\hline G4DL & 2.27 & 3.29 & 0.443 & 0.387 & 4.987 & 4.874 \\
\hline G2DD & 1.67 & 1.24 & 0.341 & 0.211 & 4.119 & 4.237 \\
\hline G4DD & 2.33 & 3.18 & 0.430 & 0.367 & 5.012 & 4.883 \\
\hline
\end{tabular}

Eatch value is expressed as mean of triplicates \pm standard deviations.

$\mathrm{G} 0=$ ungerminated, $\mathrm{G} 2 \mathrm{Dl}=2$ day germinated in light, $\mathrm{G} 4 \mathrm{DL}=4$ day germinated in light, $\mathrm{G} 2 \mathrm{DD}=2$ day germinated in dark, $\mathrm{G} 4 \mathrm{DD}=$ 4day germinated in dark

Agte and Sandhana (1997) reported that soaking of wheat batter is beneficial because it reduces phytic acid by $40 \%$.

Effect of soaking and germination on mineral contents of some legumes and cereals :

\section{Macro- elements:}

Minerals play a vital role in the maintenance of human health. Cereals and legumes are rich in minerals but the bioavailability of these minerals is usually low due to the presence of antinutritional factors such as phytate, trypsin inhibitor and polyphenoles (Nadeem et al., 2010).

Table (4) shows the macro- elements composition (ppm) such as calcium (Ca), potassium (K), magnesium $(\mathrm{Mg})$ and sodium $(\mathrm{Na})$ of ungerminated, soaked and germinated some legumes and cereal seeds in presenc that light or dark (with or without light). Data in this Table indicate soaking process (at 6 and $12 \mathrm{~h}$ ) increased macro element, this may be due to that soaking 
improved the availability of all the minerals. These results disagree with those reported by Marton et al., (2010)who reported that soaking prior to the germination is responsible for the loss of $\mathrm{Mg}$ and $\mathrm{Zn}$ that continuously emptying from the seed during the sprouting. From the tabulated data, it could be noticed that germination had varied effects on the mineral composition. On the other hand, prolonging germination to 4 day cause more decrease as compared with 2 day or soaked samples. In comparison, the mineral composition of soaked and germinated legume and cereal samples was higher in calcium than raw samples. It was observed in this study that germination process technique improved the mineral composition of the selected samples than that of raw legumes and cereals samples. This observation could be attributed to biosynthesis and activities of enzymes during germination process (Gabriel and Akharaiyi, 2007; Bau et al., 1997).

This finding indicates that the selected legume and cereal samples would serve as good sources calcium which are considered essential for bone and teeth formation and development in children. A decrease found in potassium, magnesium and sodium contents on germination comparing with raw and soaked samples (Table 4), is well documented by other authors (Enujiugha et al., 2003). This is easly observable in the lower ash contents obtained in the germinated samples. Soaking process (at 6 or 12h) on the seeds was found to cause increase changes in minerals contents of studied legumes and cereals. Presence or absence light had slightly effect or no effect on changes in minerals contents.

Absence or presence of light did not affect in the four days old pea sprouts the $\mathrm{Zn}$ and $\mathrm{Mg}$ content during the sprouting, at the same time sprouting for two and four days improved the biological availability of $\mathrm{Zn} \mathrm{Mg}$ (Urbano et al., 2006).

\section{Micro-elements :}

El-Adawy et al., (2003) reported significant increase in ash content during sprouting in mungbean, pea and lentil seed. The decrease in crude fat and carbohydrate contents during sprouting may have led to the apparent increase observed in ash and other chemical components.

There are wide applications of germinated food products besides as ingredient in normal food preparation. Some of the identified uses of germinated legumes and cereals include flour (Giami, 2004; Charoenthaikij et al., 2010), beverage (Tonella and Berry, 1987) and weaning food (Marero et al., 1988). Bread made using germinated products has increased nutritive value (Charoenthaikij et al., 2009) compared to control bread without germination. Tonella and Berry (1987) also found that chocolate beverage made from germinated chickpeas, sugar, cocoa, salt, vegetable oil and water showed reduced viscosity and improved consistency when compared with control formulated using nongerminated chickpeas (Megat Rusydi et al., 2011).

\section{CONCLUSIONS}

As shown in this study, soaking (for 6 and $12 \mathrm{hr}$ ) and germination at 2 and 4 day affected the chemical composition, antinutritional factors and nutritional quality of selected legume and cereal seeds. However, soaking processes caused smaller losses in minerals. All processes improved the in vitro starch and protein digestibility of seeds. Therefore, soaking and germination are recommended for legume and cereal seeds preparation in households and restaurants for improving the nutritional quality. Therefore, the use of processed legume and cereal flours can be exploited in functional and nutritional foods as well as a therapeutic agent in various bakery products. Since germination is cheap and more effective in improving nutritional value, it is hoped that this can contribute to nutrition of people.

\section{REFERENCES}

Abdullah, A.; Baldwin, R. E. and Minor, H. (1984). Germination effect on flatus causing factors and antinutrients of mungbeans and two strains of small seeded soybeans. Food Protection, 47: 441-444.

Agte, V. V. and Sandhana, R. J. (1997). Effect of traditional food processing on phytate degradation of wheat and millets. Food Chemistry, 45, 1659-1661.

Agustin, J., Klein, B.P., Matthews, R.H. (1989). Nutrient composition of raw cooked canned and sprouted legumes. In: Agustin, J., Klein, B.P., Matthews, R.H. (Eds.), Legumes Chemistry Technology and Human Nutrition. Marcel Dekker, New York.

Akande, K.E. and Fabiyi, E.F. (2010). Effect of processing methods on some antinutritional factors in legume seeds for poultry feeding. Intr. J. Poultry Sc., 9: 996 - 1001.

Akeson, W.E. and Stahmann, M.A. (1964). A pepsinpancreatin digestibility index of protein quality evaluation. J. Nutr., 83: 257-259.

Alaa, Y. A.; Adil, G. S. and Ibtisam, E. N. (1982). Occurrence and stability of trypsin

inhibitor in Iraqi local legumes. Journal of Agriculture and Food Chemistry, 30, 1184-1185.

Alonso, R.; Oru’ e, E.; Zabalza, M. J.; Grant, G. and Marzo, F. (2000). Effect of extrusion cooking on structure and functional properties of pea and kidney bean proteins. Journal of the Science of Food and Agriculture, 80, 397403.

AOAC, (Association of Official Analytical Chemistis) (2005). Official Methods of Analysis of the Associstion of Analytical Chemistis International, $18^{\text {th }}$ ed. Gathersburg, MD U.S.A. Official methods, 2005.08. 
Archana, S. S. and Kawatra, A. (2001). In vitro protein and starch digestibility of pearl millet (Pennisetum gluacum L.) as affected by processing techniques. Nahrung, 45: 2527.

Azizah, A.H. and Zainon, H. (1997). Effect of processing on dietary fiber contents of selected legumes and cereals. Malaysia Journal of Nutrition 3(2):131-136.

Bau, H. M.; Villaume, C.; Nicolas, J. and Méjean, L. (1997). Effect of germination on chemical composition, biochemical constituents and antinutritional factors ofsoybean (Glycine max) seeds. Journal of the Science of Food and Agriculture, 73,1-9.

Camacho, L.; Sierra, C.; Campos, R.; Guzman, E. and Marcus, D. (1992). Nutritional changes caused by the germination of legumes commonly eaten in chile. Archivos Latinoamericanos De Nutricion 42(3): 283-290.

Charoenthaikij, P.; Jangchud, K.; Jangchud, Piyachomkwan, K.; Tungtrakul, P. and Prinyawiwatkul, W. (2009). Germination conditions affect physicochemical properties of germinated brown rice flour. J. Food Sci., 74 : 658-665.

Charoenthaikij, P.; Jangchud, K.; Jangchud, A.; Prinyawiwatkul, W.; Hong, K.N. and King, J. M. (2010). Physicochemical properties and consumer acceptance of wheat-germinated brown rice bread during storage time. J. Food Sci. $75: 333-339$.

Creen, D.E.C. and Haisman, D.R. (1963). The interaction between phytic acid and divalent cations during cooking of dried peas. J. Sci. Food Agric., 14: 823-833.

Duncan, D. (1955). Multiple range and multiple F- test. Biometric, 11: 1-42. Edition, ASSOC. Office. Anal. Chem. Arlington.

Dubois, M.; Gilles, K.A.; Hamilton, J.K.; Rebers, P.A. and Smith, F. (1956). Colorimeteric method for determination of sugars and related substances. Analytical Chemistry, 28: 350-456.

Egli, I.M. (2001).Traditional Food Processing Methods to Increase Mineral Bioavailability from Cereal and Legume Based Weaning Foods. A PhD dissertation. Swiss Federal Institute of Technol Zurich.

Egli, I.; Davidsson, 1.; Juillerat, M. A.; Barclay, D. and Hurrell, R. F. (2002). The influence of soaking and germination on the phytase activity and phytic acid content of grains and seeds potentially useful for complementary feeding. Journal of Food Science, 67: 3484-3488.

El-Adawy, T.A.; Rahma, E.H.; El-Bedawey, A.A. and ElBeltagy, A.E. (2003). Nutritional potential and functional properties of germinated mungbean, pea and lentil seeds. Plant Foods for Hum. Nutr., 58: 1-13.

Enujiugha, V.N.; Badejo, A.A.; Iyiola, S.O. and Oluwamukomi, M.O. (2003). Effect of germination on the nutritional and functional properties of African oil bean (Pentaclethra macrophylla Benth) seed flour. Food Agric. Environ., 1:72-75.
Eskin, N. A. M. and Wiebe, S. (1983). Changes in phytase activity and phytate during germination of two faba bean cultivars. Journal of Food Science, 48: 270-271.

Fretzdorff, B. (1992). Phytinsaure in getreidennahrmittelnbestandsaufnahme und moglichkeiten der reduction. Getreide, Mehl and Brot 46: 180-185.

Gabriel, R. A.O. and Akharaiyi, F.C. (2007). Effect of spontaneous fermentation on the chemical composition of thermally treated jack beans (Canavalia ensiformis L.). Int. J. Biol. Chem. 1:91-97.

Giami, S.Y. (2004). Effect of germination on breadmaking properties of wheat-fluted pumpkin (Telfairia occidentalis) seed flour blends. Plant Foods for Human Nutrition 58: 1-9.

Ghavidel, R.A. and Prakash, J. (2006). Effect of germination and dehulling on functional properties of legume flours J. Sci. Food and Agric., 86: 1189-1195.

Ghavidel, R.A. and Prakash, J. (2007). The impact of germination and dehulling on nutrients, antinutrients, in vitro iron and calcium bioavailability and in vitro starch and protein digestibility of some legume seeds. LWT 40: $1292-1299$.

Gupta, C. and Sehgal, S. (1991). Development, acceptability and nutritional value of weaning mixtures. Plant Foods for Human nutrition 41: 107-116.

Hahm, T.; Park, S. and Lo, Y.M. (2008). Effects of germination on chemical composition and functional properties of sesame (Sesamum indicum L.) seeds. Bioresource Technology 100 : 1643-1647.

Hussein, L. and Ghanem, K. Z. (1999). Calcium bioavailability from selected Egyptian foods with emphasis on the impact of germination and fermentation. Inter. J.Food Sci. and Nutri., 50: 351-356.

Inyang, C.U. and Idoko, C.A. (2006). Assessment of the quality of "Ogi" made from malted mallet. Af. J. Biotechnol., 5: 2334-2337.

Inyang, C.U. and Zakari, U.M. (2008). Effect of Germination and fermentation of pearl millet on proximate, chemical and sensory properties of instant "Fura"- A Nigerian cereal food. Pak J. Nutr., 7: 9-12.

Jimenez, M.J.; Elias, L.G.; Bressani, R,; Nauarrete, D.A.; Gomez-Brenes, R. and Molina, M.R. (1985). Biochemical and nutritional studies of germinated soybean seeds. Archivos Latinoamericanos De Nutricion 35: 480-490.

Jood, S.; Chauhan, B.M. and Kapoor, A.C. (1988). Contents and digestibility of carbohydrates of chickpea and blackgram as affected by domestic processing and cooking. Food Chem. 34: 417-420.

Jood, S.; Bishnoi, S. and Segal, S. (1998). Effect of processing on nutritional and antinutritional factors of moungbean cultivars. Journal of Food Biochemistry, 22, 245257

Kakade, M. L., Simons, N., and Liener, I. E. (1969). An evaluation of natural vs. synthetic substrates for measuring the antitryptic activity of soy bean samples. Cereal Chemistry 46: 518-528. 
Kamchan, A.; Puwastien, P.; Sirichakwal, P. P. and Kongkachuichai, R. (2004). In vitro calcium bioavailability of vegetables, legumes and seeds. Journal of Food Composition and Analysis 17: 311-320.

Kaushik, G., Satya, S. and b Naik, S.N. (2010). Effect of domestic processing techniques on the nutritional quality of soybean. Mediterr. J. Nutr. Metab. 3, 39-46.

Khalil, A.W.; Zeb, A.; Mahmood, F.; Tariq, S.; Khattak, A.B. and Shah, H. (2007). Impact of germination time on comparative sprout quality characteristics of desi and Kabuli type chickpea cultivars (Cicer arietinum L). LWT-Food Sci. Technol., 103:115-120.

Kyriakidis, N. B.; Panayotou, M. G.; Stavropoulou, A. and Athanasopoulos,P. (1998). Increase in phytase activity and decrease in phytate during germination of four common legumes. Biotechnology Letters, 20(5): 475-478.

Lasekan, O.O. (1996). Effect of germination on $\alpha$ - amylase activities and rheological properties of sorghum (Sorghum biocolar) and acha (Digitaria exilis) grains. J. Food Sci. Technol., 33: $329-331$.

Lorenz, K. (1980). Cereal sprouts: Composition, nutritive value, food applications. Critical Review of Food Sc. And Nutr., 13: 353-385.

Maisont, S. and Narkrugsa, W. (2010). The effect of germination on GABA content, chemical composition, total phenolics content and antioxidant capacity of Thai waxy paddy rice. Kasetsart J. Nat. Sci., 44: 912 923.

Marrero, L.M.; Payumo, E.M.; Librando, E.C.; Lainez, W.N.; Gopez, M.D. and Homma, S. (1988). Technology of weaning food formulations prepared from germinated cereals and legumes. Journal of Food Science 53: 13911395.

Marton, M.; Mandoki,Z.; Csapo-Kiss, Z. and Csapo, J.(2010). The Role of Sprouts in Human Nutrition. A review. Acta Univ. Sapientiae, Alimentaria 3: 81-117.

Megat Rusydi, M.R.; Noraliza, C.W.; Azrina, A. and Zulkhairi, A. (2011). Nutritional changes in germinated legumes and rice varieties. Inter. Food Res. J. 18: 705 713.

Miller,G.L. (1959). Use of dinitrosalicylic acid reagent for determination of reducing sugars. Anal. Chem., 31: 426-428.

Miller, B.F. (1978). Proc. $10^{\text {th }}$ Natl. Conf. Wheat Util. Res. No. ARMW-4. P. 144.

Moongngarm, A. (2011). Influence of germination conditions on starch, physicochemical properties and microscopic structure of rice flour. Intr. Conference on Biology Enviro. \& Chem., 1: $78-82$.

Negi, A.; Boora, P. and Khetarpaul, N. (2001). Starch and protein digestibility of newly released moth bean cultivars: Effect of soaking, germination and pressure-cooking. Nahrung 45: 251-254.
Nielsen, M.T.; Meade, R.E.; Paulsen, G.M. and Hoseney, R.C. (1978). Improvement of wheat protein quality by germination. Proc. $10^{\text {th }}$ Natl. Conf. Wheat Util. Res. No. ARM-W-4. P.16.S

Nzeribe, H.C. and Nwasike, C.C. (1995). The brewing potential of acha (Digiteria exlils) malt compared with pearl millet (Pennisetum glaucum) malt and sorghum (Sorghum bicolar) malts. J. Inst. Brewing 101: 345-350.

Nonogaki, H.; Bassel, G.W. and Bewley, J.W. (2010). Germination-still a mystery. Plant Science doi:10.1016/j.

Obizoba, I. C. and Atii, J. V. (1994). Evaluation of the effect of processing techniques on the nutrient and antinutrient contents of pearl millet (Pennisetum glaucum) seeds. Plant Foods for Human Nutrition, 45, 23-34.

Ohtsubo, K.; Suzuki, K.; Yasui, Y. and Kasumi, T. (2005). Bio-functional components in the processed pregerminated brown rice by a twin-screw extruder. Journal of Food Composition and Analysis 18 : 303-316.

Oloyo, R.A. (2004). Chemical and nutritional quality changes in germinating seeds of Cajanus cajaan L. Food Chem., 85: 497-502.

Osman, M.A. (2007). Effect of different processing methods, on nutrient composition, antinutritional factors, and in vitro protein digestibility of Dolichos Lablab sweet bean ( Lablab purpuresus L). J. Nutr., 6: 299-303.

Punder, K. and Pruimboom, L. (2013). The dietary intake of wheat and other cereal grains and their role in inflammation. Nutrients 5:771-787.

Riddoch, C.H.; Mills, C.F. and Duthie, G.G. (1998). An evaluation of germinating beans as a source of vitamin $\mathrm{C}$ in refugee foods. Eur. J. Clin. Nutr., 52: 115-118.

Rodriguez, C.; Frias, J.; Vidal-Valverde, C. and Hernandez, A. (2008). Correlations between some nitrogen fractions, lysine, histidine, tyrosine and ornithine contents during the germination of peas, beans and lentils. Food Chem., 108: 245-252.

Saastamoinen, M.; Kumpulainen, J. and Nummela, S. (1989). Genetic and environmental variation of oil content and fatty acids composition of oats. Cereal Chem., 66: 296300.

Sangronis, E. and Machado, C.J. (2007). Influence of germination on nutritional quality of Phaseous vulgaris and Cajanus cajan. J. Sci. Tech. 40: 116-120.

Singh, U.; Khedekar, M.S. and Jambunathan, R. (1982). Studies on desi and kabuli chickpea cultivars. The level of amylase inhibitors, levels of oligosaccharides and in vitro starch digestibility. J. Food Sci., 47: 510-516.

SPSS (1997): Spss users Gide statistics version 8. Copy right Spss Inc., USA, Washington, D. C. USA.

Tatsadjieu, N.L.; Etoa F-X and Mbofung C.M.F. (2004). Drying Kinetics, Physicochemical and nutritional characteristics of "Kindimu", a fermented milk- basedsorghum-flour. The Journal of Food Technology in Africa 9(1):17-22. 
Tian, B,; Xie, B.; Shi, J.; Wu, J.; Cai, Y.;Xu, T.; Xue, S. and Deng, Q. (2010). Physicochemical changes of oat seeds during germination. Food Chem., 119: 1195-1200.

Tonella M.L. and Berry, J.W. (1987). Characteristics of a chocolate beverage from germinated chickpeas. Journal of Food Science 52: 726-728.

Traoré, T.; Mouquet, C.; Icard-Verniere, C.; Traore, A,S. and Treche, S. (2004). Changes in nutrient composition, phytate and cyanide contents and $\alpha$-amylase activity during cereal malting in small production units in Ouagadougou (Burkina Faso). Food Chem., 88:105-114.

Urbano, G.; Aranda, P.; Vilchez, A., Aranda, C.; Cabrera, L. and Porres, J. S. M. (2005). Effects of germination on the composition and nutritive value of proteins in Pisum sativum, L.. Food Chemistry, 93, 671-679.

Urbano, G.; Lopez-Jurado,M.; Aranda,C.; Vilchez,A.; Cabrera,L.; Porres, J.M. and P. Aranda, P.(2006). Evaluation of zinc and magnesium bioavailability from pea (Pisum sativum L.) sprouts. Effect of illumination and different germination periods. Inter. J. Food Sci. and Techno., 41: 618-626.

Uriyo, M. G. (2001). Changes in enzyme activities during germination of cowpeas (Vigna unguiculata, cv. California blackeye). Food Chem., 73: 7-10.

Vidal-Valverde C, Frias J. and Esteban E. (1992). Dietary fiber in processed lentils. J Food Sci., 57:1161-1163.
Vidal-Valverde C.; Frias J.; Estrella, I.; Gorospe, M.J.; Ruiz R. and Bacon J. (1994). Effect of processing on some antinutritional factors of lentils. J Agric Food Chem., 42:2291- 2295

Vidal-Valverde, C., Fri'as, J., Sierra, I., Blazquez, I., Lambien, F., Kuo, Y-H. (2002). New functional legume food by germination. Effect on the nutritive value of beans, lentils and peas. European Food Research and Technology 215, 472-476.

Wang, N.; Lewis, M. J.; Brennan, J. G. and Westby, A. (1997). Effect of processing methods on nutrients and antinutritional factors in cowpea. Food Chemistry, 58, 5968.

Wheeler, E.I. and Ferrel, R.E. (1971). A method for phytic acid determination in wheat and wheat fractions. Cereal Chemistry 48: 312-316.

Yang, F.; Basu, T.K. and Ooraikul, B. (2001). Studies on germination conditions and antioxidant contents of wheat grain. International Journal of Food Science and Nutrition 52: 319-330.

Zanabria, E.R.; Katarzyna, N.; De Jong, L.E.Q.; Birgit, H.B.E. and Robert, M.J.N. (2006). Effect of food processing of pearl millet (Pennisetum glaucum) on the level of phenolics, phytate, iron and zinc. J. Sc. Food and Agric., 86: $1391-1398$. 


\section{الملخص العربي}

\section{تأثير عمليات النقع والأنبات على التركيب الكيماوى، مكونات الكربوهيدرات، المواد المضادة}

\section{للتغذية، الهضمية ومحتوى المعادن لبعض بذور البقوليات والحبوب}

$$
\text { سامية الصافف فرج، رباب حسن عبد الرازق، أنصاف مختار ياسين }
$$

الكربوهيدرات والدهن. يؤدى النقع والإنبات لزيادة المضمية المعملية لكل من النشا والبروتين وإنخفاض محتويات كل من حمض الفيتيك ومثبطات التربسين، والإنغفاض في حض الفيتيك ومثبطات التربسين يكون بسبب التغيرات الإنزيمية خلال فترة النقع والإنبات. وتشير النتائج عدم وجود تأثير (أو تأثير طفيف) للضوء خلال عملية الإنبات على المكونات المختلفة. ويمكن أستنتاج أن عمليات النقع والإنبات تحسم من الحالة الغذائية للبقوليات والحبوب موضع الدراسة من حيث

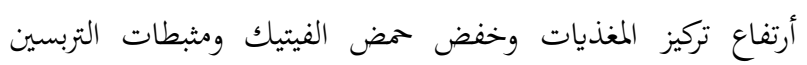
وتحسين البروتين وحض الأسكوربيك. يمكن أدخال الحبوب والبقول المنبتة في الأغذية التى تعتمد في تصنيعها على القمح مثل الخبز والمكرونة لرفع قيمتها الغذائية.
تؤدى عمليات النقع والإنبات لبذور البقوليات والحبوب إلى بعض

التغيرات فن الخصائص الكيموحيوية والغذائية للبقوليات والتى لها فوائد على صحة الإنسان، وكذلك الحالة الغذائية. في هذه الدراسة تم تقييم عمليات النقع لمدة 6، 12 ساعة الإنبات لمدة 2، 4 يوم بدون أو

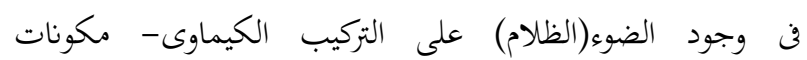
الكربوهيدرات(النشا- السكريات الكلية- السكريات المختزلةالكربوهيدرات الكلية بالفرق)، وعلى هضمية كل من النشا والبروتين، وكذلك دراسة العوامل المضادة للتغذية وحتويات المعادن(الكبرى والصغرى) لبعض البقوليات (البسلة- العدس-الحمص-الفول البلدى) والحبوب (الشوفان-القمح). أوضحت النتائج حدوث زيادة فن محتويات الرطوبة والبروتين في العينات المنبتة في حين الخفضت محتويات 